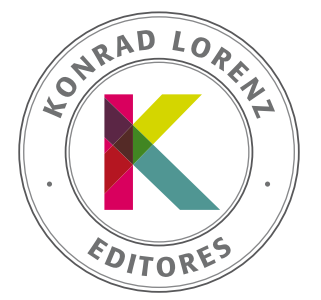

\title{
Exercise addiction in Mexico: Psychometric properties of the Exercise Addiction Inventory and risk analysis
}

\author{
Dahiana Salazar a, Abril Cantú a, Andrés Ceballos b, Rosendo Berenguií c,* \\ ${ }^{a}$ Federación Mexicana de Fútbol, Ciudad de México, México \\ ${ }^{b}$ Facultad de Organización Deportiva, Universidad Autónoma de Nuevo León, Monterrey, México \\ 'Facultad de Ciencias Sociales y de la Comunicación, Universidad Católica de Murcia, Murcia, España
}

Received 16 September 2020; accepted 29 April 2021

\section{KEYWORDS:}

Exercise addiction, exercise dependence, addictive behaviour, EAI, sport

\begin{abstract}
Introduction: The consequences of exercise addiction have a physical, psychological and social impact on the sports men and women, similar to others addictions, which can cause serious health problems. In Mexico its incidence and relevance are unknown, and there is no instrument for its evaluation. This study aims to analyse the psychometric properties of the Exercise Addiction Inventory in a Mexican context and examine its relevance to different groups of people who practice sport. Method: Participants consisted of 487 people who practice physical exercise or competitive sport, aged between 18 and 52, with a mean age of 22.04. The EAI was used, and reliability analysis, confirmatory factor analysis and factorial invariance analysis were conducted. Differences between groups of participants were also tested. Results: The results demonstrated the unifactorial structure of instrument, with satisfactory goodness of fit indices, and its factorial invariance was confirmed. The reliability obtained was adequate. In addition, significant differences were found between men and women in relation to degree of addiction, there was a higher risk for athletes compared to regular exercise goers, and $26.5 \%$ of participants obtained scores that place them at a high risk of exercise addiction. Conclusions: It is concluded that EAI is an adequate and reliable instrument, with appropriate psychometric properties. In the studied population there is an excessively high rate of participants who present a high risk of addiction, and men and athletes are the most susceptible groups to develop an exercise addiction.
\end{abstract}

(O2021 Fundación Universitaria Konrad Lorenz. This is an open access article under the CC BY-NC-ND license (http://creativecommons.org/licenses/by-nc-nd/4.0/).

\footnotetext{
* Corresponding author.

E-mail: rberengui@ucam.edu
} 


\section{PALABRAS CLAVE:}

Adicción al ejercicio, dependencia al ejercicio, comportamiento adictivo, EAI, deporte

\section{Adicción al ejercicio en México: propiedades psicométricas del Exercise Addiction Inventory y análisis de riesgo}

Resumen Introducción: Las consecuencias de la adicción al ejercicio físico impactan de manera física, psicológica y social en el practicante, de forma similar a otras adicciones, pudiendo ocasionar serios problemas para su salud. En México se desconoce su incidencia y relevancia, y no se dispone de instrumentos para su evaluación. El objetivo de este artículo fue analizar las propiedades psicométricas del Exercise Addiction Inventory en el contexto mexicano, y examinar su relevancia en diferentes grupos de practicantes. Método: Participaron 487 practicantes de ejercicio físico o deporte competitivo, de edades entre 18 y 52 años, y una media de edad de 22.04 años. Se empleó el EAl, y se realizaron análisis de fiabilidad, análisis factorial confirmatorio y de invarianza factorial. También se comprobaron las diferencias entre grupos de participantes. Resultados: Los resultados demostraron la estructura unifactorial del instrumento, con índices de bondad y ajuste satisfactorios, y se confirma su invarianza factorial. La fiabilidad obtenida fue adecuada. Además, se encontraron diferencias significativas entre hombres y mujeres con relación al grado de adicción, mayor riesgo de los deportistas frente a practicantes habituales de ejercicio, y un $26.5 \%$ de participantes que obtienen puntuaciones que los sitúan en alto riesgo de adicción al ejercicio. Conclusiones: Se concluye que el EAI se muestra como un instrumento adecuado y fiable, con apropiadas propiedades psicométricas. En la población estudiada hay una tasa excesivamente alta de participantes que presentan un elevado riesgo de adicción, siendo los hombres y los deportistas los grupos con mayor susceptibilidad a padecerla.

(C) 2021 Fundación Universitaria Konrad Lorenz. Este es un artículo Open Access bajo la licencia CC BY-NC-ND (http://creativecommons.org/licenses/by-nc-nd/4.0/).
Exercise is a form of physical activity that is carried out in a planned, structured and repetitive manner, and through which a series of positive effects on health are obtained, which reduce the risk of disease (US. Department of Health and Human Services, 2008). However, to achieve the different objectives in relation to exercise practice, some people may exercise without limits, making it counterproductive to what the participant wants to achieve. This led researchers to investigate and accept that, in some cases, exercise can be detrimental to health (Szabo, 1998, 2000) and become an addictive behaviour (Griffiths, 1996, 2002), causing alterations both physically and psychologically (Márquez \& De la Vega, 2015; Simón-Grima et al., 2019).

Exercise addiction is characterised by excessive and obsessive exercise patterns, an abnormal dependence that manifests itself in physiological and/or psychological symptoms (Berengüí \& Pelegrín, 2018). Exercise addiction has been defined as a strong desire to exercise, becoming more important than other spheres of life, such as family, social relations, work, etc., and is characterized by the lack of control and maintenance of behaviour, despite the negative consequences, causing withdrawal symptoms when spending several days without exercising (Goodman, 1990; Hausenblas \& Symons-Downs, 2002; Szabo, 1995, 1998, 2000; Youngman \& Simpson, 2014). Therefore, exercise addiction can be considered a real problem with a great impact, because it may lead to risky behaviours (Berengüí et al., 2021).

Taking into account the six general components of addictions (Brown, 1993), which Griffiths (1996, 1997, 2002) adapted to exercise: (1) Salience: occurs when exercise becomes the most important activity in a person's life and dominates their thoughts, feelings and behaviour; (2) Conflict: between the person and those around him or her (e.g., interpersonal conflict), conflicts with other activities (e.g., work, social life, hobbies and interests), or in the individual themselves (e.g., intrapsychic conflict); (3) Mood modification: refers to experiences that people report as a result of exercising; (4) Tolerance: the process in which a person requires increasing amounts of exercise to achieve desired physical, social, psychological and/or emotional effects; (5) Withdrawal symptoms: these are unpleasant emotional states and/or physical effects that occur when the activity is interrupted or is suddenly reduced; (6) $R e$ lapse: a tendency to return to the same amount of exercise patterns after a certain time of enforced inactivity.

Driven by this approach, Terry et al., (2004) created the Exercise Addiction Inventory (EAI), consisting of six items that integrate a single factor, which correspond to those six components of addiction already mentioned. The instrument has been used in various investigations that have provided an empirical basis for the study of exercise addiction worldwide. There are adaptations and studies of their properties in different countries, like the United Kingdom (Griffiths et al., 2005; Terry et al., 2004), Spain (Sicilia et al., 2013; Szabo, et al., 2013), Hungary (Demetrovics \& Kurimay, 2008; Kovacsik et al., 2019; Mónok et al., 2012), Denmark (Lichtenstein, Christiansen et al., 2014; Lichtenstein et al., 2018; Lichtenstein, Larsen et al., 2014), Italy (Villella et al., 2011), and Brazil (Sicilia et al., 2017). In these studies, the instrument showed adequate psychometric properties, and confirmed unifactorial validity and appropriate reliability.

We should point out that there are other instruments that measure exercise addiction: the Exercise Dependence Scale - Revised, (EDS-R, Symons-Downs et al., 2004), also validated in different countries (e.g., the Spanish version by Sicilia and González-Cutre, 2011), the Obligatory Exercise Questionnaire (OEQ, Pasman \& Thompson, 1988), and the Exercise Dependence Questionnaire (EDQ, Ogden et 
al., 1997). The EDS-R and EAI are currently the most widely used instruments, due to their short application time and easy scoring, and have been shown to produce comparable results when used together (Berczik et al., 2012). For the present research, the EAl was used because it is driven by the theory applied to the general addiction criteria in order to investigate exercise addiction in athletes, and is aligned with the new classification system provided by the DSM-V (American Psychiatric Association, 2013).

In Mexico, exercise addiction has not been analysed so far, and due to its important health repercussions, it is necessary to have an instrument adapted to the Mexican context in order to assess addiction risk. Having an appropriate measuring instrument will identify the risk of sports men and women, as well as serve as a basis for creating prevention and intervention programs to reduce suffering from this addiction. This facilitates the reduction of maladaptive behaviours in people's lives, thus promoting their quality of life. Based on the above, the present study aims to analyse the psychometric properties of the Exercise Addiction Inventory (EAl, Terry et al., 2004) in the Mexican context, and examine its relevance in people who practise sport.

\section{Method}

\section{Participants}

Four hundred and eighty-seven subjects participated in the study, 240 men (49.3\%) and 247 women (50.7\%), aged 18 to $52(M=22.04, S D=5.38)$. Participants were physically active university students ( $n=148 ; 49.0 \%$ men and $51.0 \%$ women; mean age $=19.71, D T=2.23$ ), athletes participating in Mexico's National Sports Universiade ( $n=195$; 40.1\% men and 59.9\% women; mean age $=21.03$; $D T=1.97$ ), and people who perform regular physical exercise several days a week ( $n=144 ; 60.2 \%$ men and $39.8 \%$ women; mean age $=27.96, D T=8.74)$. The average weekly training was 4.46 days $(S D=1.52)$, and $10.73(S D=6.21)$ hours of training. Disciplines practiced by most participants are fitness and gym activities ( $n=72$ ), running $(n=53)$, basketball $(n=50)$, track and field $(n=49)$, and soccer $(n=49)$.

\section{Instrument}

Exercise Addiction Inventory (EAl; Terry et al., 2004). Table 1 shows the six items that make up the instrument and addiction component to which it belongs, according to a modified version of the components of behavioural addiction (Griffiths, 1996). The instrument has a Likert scale response ranging from (1) Strongly Disagree to (5) Strongly Agree. In both studies (Sicilia et al., 2013; Terry et al., 2004), scores of 24 or more indicate a risk of exercise addiction, scores between 13 and 23 mean that the subject has certain symptoms, and scores between 6 and 12 imply the absence of symptoms. EAl has presented adequate psychometric properties, with a reliability (Cronbach's alpha) of $\alpha=.84$ for the original scale (Terry et al., 2004), and $\alpha=.70$ for the Spanish adaptation (Sicilia et al., 2013).
Table 1 Items of Exercise Addiction Inventory and components associated with behavioural addiction

\begin{tabular}{lc}
\hline \multicolumn{1}{c}{ Items } & $\begin{array}{c}\text { Addiction } \\
\text { component }\end{array}$ \\
\hline 1. Exercise is the most important thing in my & Salience \\
life. [El ejercicio es la parte más impor- & \\
tante de mi vida] & \\
2. Conflicts have arisen between me and & Conflict \\
my family and/or my partner about the & \\
amount of exercise I do. [Han surgido con- & \\
flictos con mi familia y/o mi pareja acerca & \\
de la cantidad de ejercicio que realizo] & \\
3. I use exercise as a way of changing my & Mood \\
mood. [Uso el ejercicio como una forma de & modification \\
cambiar mi estado de ánimo] & \\
4. Over time I have increased the amount of & Tolerance \\
exercise I do in a day. [Con el tiempo he & \\
aumentado la cantidad de ejercicio que & \\
hago en un día] & \\
5. If I have to miss an exercise session, I feel & Withdrawal \\
moody and irritable. [Si tengo que faltar & symptoms \\
a una sesión de entrenamiento me siento & \\
irritable y de mal humor] & \\
6. If I cut down on the amount of exercise & Relapse \\
I do, and then start again, I always end & \\
up exercising as often as I did before. [Si & \\
reduzco la cantidad de ejercicio, y luego & \\
vuelvo a empezar, siempre intento hacer & \\
tanto ejercicio como hacía] & \\
\hline
\end{tabular}

\section{Procedure}

The process started with an analysis of the instrument. This was conducted by four experts in sports psychology, based on the adaptation into Spanish by Sicilia et al. (2013). The content of the items and their appropriateness to the Mexican context was evaluated. There was total agreement on the appropriateness of the items, their content and the cultural and contextual appropriateness of the text.

Subsequently, applications were made in order to obtain the sample of each group other than the population. They were informed only about the purpose of the research, and they were given informed consent, in which the confidentiality of their data and of the scientific use of information was established in writing. Data collection was carried out at three different times. First, during the National Universiade Sports Competition event between public and private universities in the country. Subsequently, in classrooms of different faculties of the Autonomous University of Nuevo Leon (Monterrey, Mexico). Thirdly, in different private running clubs and gyms in the metropolitan area of Nuevo Leon, Mexico.

The study was conducted according to the guidelines of the Declaration of Helsinki, and approved by the Research Coordination of the Faculty of Sports Organization, Autonomous University of Nuevo Leon (registration number: REPRIN-FOD-62; date of approval: 29 February 2020). 


\section{Data analysis}

Different statistical analyses were performed using the IBM SPSS Statistics 24 package. Descriptive statistics were obtained, including asymmetry and kurtosis of items, internal consistency analysis (Cronbach's Alpha), and factor invariance analysis according to gender. For the correlations analysis between items and between EIA scores and age, training days and hours, a Pearson coefficient was used. To examine gender differences a student's t-test was used, to analyse differences between groups of practitioners, an analysis of variance (ANOVA) and Bonferroni post hoc analysis were performed, and an eta square statistic $\left(\eta^{2}\right)$ was used to quantify differences magnitude.

Confirmatory factor analysis (CFA) was performed through the LISREL v8.8 program (Jöreskog \& Sörbom, 2006). The indicated model fit was checked from different indices: chi-square and the degrees of freedom, Root Mean Square Error of Approximation (RMSEA), Comparative Fit Index (CFI), Non-Normed Fit Index (NNFI), TLI (Tucker-Lewis Index), and SRMR (Standardized Root Mean Square Residual).

\section{Results}

\section{Descriptive statistics, correlation analysis and in- ternal consistency analysis.}

The results of the descriptive statistics of the items are shown in Table 2, where the results show that the average of the items ranges between 2.34 and 3.39, and the standard deviation between 1.23 and 1.47. For asymmetry and kurtosis, they reflect a normal distribution, and are within the accepted parameters [-2, 2].

Pearson's correlation analysis (see Table 2 ) showed positive and significant associations between all items $(p<.01)$. Likewise, reliability analysis and internal consistency was performed through Cronbach's alpha coefficient, in which an adequate result was obtained $(\alpha=.81)$.

\section{Confirmatory factor analysis}

A confirmatory factor analysis was performed where the indices of goodness of fit which assessed the adequacy of the model were satisfactory: $\chi^{2}=31.57 ; g l=9$; RMSEA $=.065$; $\mathrm{CFI}=.982 ; \mathrm{NNFI}=.977 ; \mathrm{TLI}=.970 ; \mathrm{SRMR}=.047$. The factorial loads of items were greater than .50 , which are within the accepted parameters.

\section{Analysis of factorial invariance across gender.}

An analysis of scale factorial invariance was performed to study the equality of the model according to gender. Results revealed a good model fit for both sexes, with relatively equal model fit statistics. Table 3 shows results obtained in different models tested.

Differences in the value of $\chi^{2}$ were observed between the unrestricted model and the following models: measurement weights, structural covariances and measurement residues. Although this value exceeds that required to accept the invariance hypothesis. GFI $=.967, \mathrm{CFI}=.939, \mathrm{RM}$ SEA $=.074$ and AIC $=120.138$ indices, allow us to accept base invariance model (unrestricted model). Figure 1 shows confirmatory factor analysis and factorial invariance of Exercise Addiction Inventory in men and women.

\section{Risk analysis and group differences.}

Regarding estimates of addiction prevalence, $26.5 \%$ of the sample $(n=129)$ obtained a total score of 24 or more, which classified them as being at risk of having an exercise addiction, $56.5 \%(n=275)$ obtained scores of between 12 and 23 , which classified them as a symptomatic group, and 17.0\% ( $n=83)$ had scores between 6 and 12, which classified them as being as atic (Table 4).

Table 2 Descriptive statistics and correlations between items of EAl

\begin{tabular}{ccccccccccc}
\hline Items & $M$ & SD & Asymmetry & Kurtosis & $\mathbf{1}$ & $\mathbf{2}$ & $\mathbf{3}$ & $\mathbf{4}$ & $\mathbf{5}$ \\
\hline 1. & 3.30 & 1.24 & -.26 & -.81 & & & & & \\
2. & 2.35 & 1.42 & .59 & -1.08 & $.26^{* *}$ & & & & \\
3. & 3.64 & 1.29 & -.66 & -.63 & $.46^{* *}$ & $.25^{* *}$ & & & \\
4. & 3.38 & 1.36 & -.44 & -.99 & $45^{* *}$ & $.28^{* *}$ & $.54^{* *}$ & & \\
5. & 2.77 & 1.46 & .21 & -1.31 & $.42^{* *}$ & $.48^{* *}$ & $.45^{* *}$ & $.50^{* *}$ & \\
6. & 3.31 & 1.33 & -.32 & -.99 & $.42^{* *}$ & $.29^{* *}$ & $.49^{* *}$ & $.58^{* *}$ & $.52^{* *}$ \\
EAI & 3.13 & .97 & & & $.68^{* *}$ & $.61^{* *}$ & $.73^{* *}$ & $.77^{* *}$ & $.79^{* *}$ & $.76^{* *}$ \\
\hline
\end{tabular}

Note: ${ }^{* *} p=0.01$

Table 3 Goodness of fit indices for models tested in factorial invariance

\begin{tabular}{|c|c|c|c|c|c|c|c|}
\hline & $\chi^{2}$ & $d f$ & CFI & GFI & RMSEA & SRMR & AIC \\
\hline Unrestricted model & 72.138 & 18 & .939 & .953 & .074 & .062 & 120.138 \\
\hline Measurement weights & 75.076 & 23 & .941 & .951 & .068 & .064 & 113.076 \\
\hline Structural covariances & 84.982 & 24 & .931 & .945 & .072 & .084 & 120.982 \\
\hline Measurement residues & 95.208 & 30 & .929 & .937 & .067 & .087 & 119.208 \\
\hline
\end{tabular}

Note: $\chi^{2}=$ chi-square; $\mathrm{df}=$ degrees of freedom; $\mathrm{CFI}=$ Comparative Fit Index; GFI = Goodness of Fit Index; RMSEA = Root Mean Square Error of Approximation; SRMR = Standardized Root Mean Square Residual; AIC = Akaike Information Criterion. 


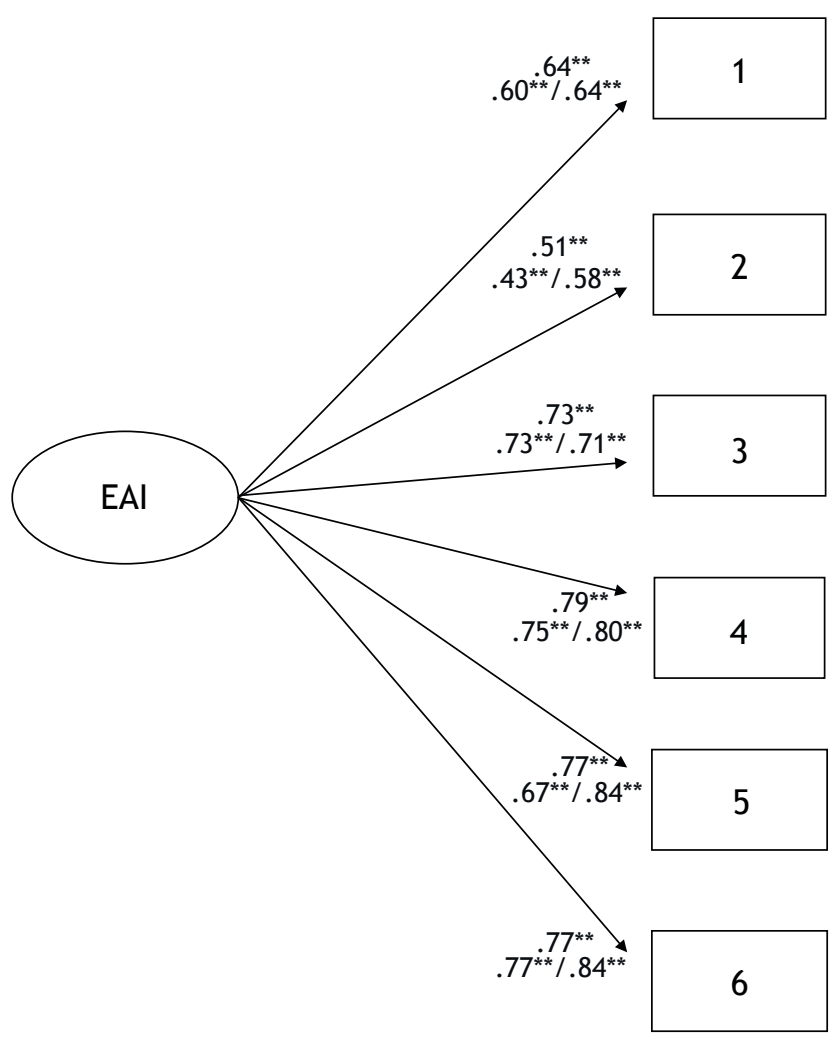

Figure 1. Confirmatory factor analysis and invariance by gender $(\mathrm{M} / \mathrm{W})$ of EAl.

Concerning correlation analysis, there are significant correlations between EAl scores and training days $(r=.364$; $p<.001)$, and training hours $(r=.328 ; p<.001)$. Correlation is negative between risk scores and age $(r=-.299 ; p<.001)$.

Regarding gender variables, significant differences were found between men and women in relation to degree of addiction $\left(t_{485}=2,971 ; p<.01\right)$. Men have an average of 19.54 in EAI (SD = 5.22) and women 17.98 (SD = 6.30). Based on the proportion of men and women in risk groups, there are frequency differences between both sexes $\left(\chi^{2}=14,820\right.$; $p<.001)$. The percentage of exercise addiction risk is higher in men (27.92\%) compared to women (25.10\%). Likewise, men report a higher percentage in symptomatic addiction (61.66\%), unlike women (51.42\%). Also, women have a higher percentage in the asymptomatic grade $(23.48 \%)$ compared to men (10.42\%). No significant differences were found between men and women regarding days and hours dedicated to training.

Likewise, through ANOVA a comparison was made between physical-sports practice groups and degree of addiction (Table 4), there being significant differences among groups $[F(2,484)=54,825 ; p<.001]$, and effect size is large. Post hoc analyses revealed differences between students and practitioners $(I-J=4.688 ; p<.001)$, and between athletes and students $(I-J=5.852 ; p<.001)$. There were no differences between regular practitioners and athletes. Differences between groups were also recorded in terms of days and hours of weekly training.

\section{Discussion}

The purpose of this study was to analyse the psychometric properties of the Exercise Addiction Inventory (EAI; Terry et al., 2004) in the Mexican context, and examine its relevance in terms of exercise and sports practitioners.

Through different analyses, EAl achieves appropriate psychometric properties. Reliability of inventory was acceptable and superior to that obtained in adaptations to other languages and countries, such as Hungary (Mónok et al., 2012), Spain (Silicia et al., 2013) and Denmark (Lichtenstein, Christiansen et al., 2014), and is similar to that obtained with the original scale in the British context (Terry et al., 2004).

Based on instrument factorial validity, we agree with the authors of previous studies that support the EAI unifactorial validity (Griffiths et al., 2005; Griffiths et al., 2015; Kovacsik et al., 2019; Lichtenstein, Christiansen et al., 2014; Lichtenstein, Larsen et al., 2014; Lichtenstein et al., 2018; Mónok et al., 2012; Szabo et al., 2013; Terry et al., 2004).

Confirmatory factor analysis reflected acceptable indices for the model and factor loads greater than .50 (Hu \& Bentler, 1999; Wheaton et al., 1977). The invariance was also confirmed. Although invariance has usually been evaluated through the calculation of differences obtained in $\chi^{2}$, in this study the criteria for evaluation of Cheung and Rensvold (2002) models are followed, which recommend evaluating the difference in CFI values. If the CFI difference calculation of both tested models decreases by .01 or less, the restricted model is considered good, and therefore

Table 4 Exercise addiction differences among practitioner groups

\begin{tabular}{|c|c|c|c|c|c|c|c|c|c|}
\hline & \multicolumn{2}{|c|}{$\begin{array}{c}\text { Asymptomatic } \\
(n=83)\end{array}$} & \multicolumn{2}{|c|}{$\begin{array}{c}\text { Symptomatic } \\
(n=275)\end{array}$} & \multicolumn{2}{|c|}{$\begin{array}{c}\text { Addiction risk } \\
(n=129)\end{array}$} & \multirow[b]{2}{*}{$\boldsymbol{F}$} & \multirow[b]{2}{*}{$p$} & \multirow[b]{2}{*}{$\eta^{2}$} \\
\hline & $M$ & $S D$ & $M$ & $S D$ & $M$ & $S D$ & & & \\
\hline Exercise Addiction (EAI) & 9.42 & 2.25 & 18.25 & 2.59 & 25.81 & 2.22 & 1143.291 & .000 & .825 \\
\hline Training days & 2.90 & 1.04 & 4.39 & 1.48 & 4.95 & 1.40 & 18.987 & .000 & .094 \\
\hline \multirow[t]{3}{*}{ Weekly hours } & 6.04 & 5.39 & 10.55 & 6.14 & 12.26 & 6.04 & 11,777 & .000 & .064 \\
\hline & \multicolumn{2}{|c|}{$\begin{array}{l}\text { Students } \\
(n=148)\end{array}$} & \multicolumn{2}{|c|}{$\begin{array}{l}\text { Regular practitioners } \\
\qquad(n=144)\end{array}$} & \multicolumn{2}{|c|}{$\begin{array}{l}\text { Athletes } \\
(n=195)\end{array}$} & & & \\
\hline & $M$ & $S D$ & $M$ & $S D$ & $M$ & $S D$ & $F$ & $p$ & $\eta^{2}$ \\
\hline Exercise Addiction (EAl) & 15.02 & 5.67 & 19.71 & 5.10 & 20.87 & 5.12 & 54.825 & .000 & .185 \\
\hline Training days & 3.13 & 1.48 & 4.65 & 1.41 & 4.81 & 1.39 & 33.604 & .000 & .140 \\
\hline Weekly hours & 8.01 & 5.82 & 9.02 & 4.88 & 13.12 & 6.36 & 31.485 & .000 & .133 \\
\hline
\end{tabular}


complies with invariance. In this case, the value of $\triangle C F I$ is less than .01.

Concerning the estimates of exercise addiction prevalence in the Mexican context, it was identified that $26.5 \%$ of the participants are at risk of suffering from exercise addiction, according to the addiction rates of Terry et al. (2004). This percentage is an important contribution to the study of exercise addiction, since no scientific publications were found in a Mexican context in which similar parameters were obtained. According Terry et al. (2004), scores of 24 or higher in EAl were reached by $3 \%$ of subjects, and $14.9 \%$ in the Silicia et al. (2013) study; although, a high percentage of the present study is evident. One explanation for this high rate may be related to the age of the participants, mostly university students and young people. The results of this study are consistent with previous studies on a negative relationship between age and addiction (Simón-Grima et al., 2019, 2021), in the sense that as the subject's age increases, his or her exercise addiction decreases. For example, Szabo and Griffths (2007) found more addiction symptoms in students (19-23 years old), than in the general exercising population (17-74 years), and what's more, Garman et al. (2004) also obtained results that reported a high incidence of exercise addiction among students in Health and Physical Education.

However, prevalence analysis in this study field is very complex. Prevalence in different studies range between 0.3-0.5\% for the general population (Mónok et al., 2012) and 42.5\% in gym attenders (Bruno et al., 2014). The systematic review by Marques et al. (2018) concluded that people who exercised regularly, showed a prevalence of addiction between 1.9 - 42.0\%, non-sports university students between $3-21.4 \%$, athletes between $1.4-17.0 \%$, and the general population between $0.3-6.4 \%$. But we must consider that this disparity in results may be due to many factors. So, for example, research has analysed addiction based on different meanings of the concept, a multitude of varied evaluation instruments have been used, and the populations and samples analysed have been very diverse. Therefore, taking into account design and particular characteristics of the sample in this study, percentages should be taken with caution.

On the other hand, existing differences according to gender were analysed, revealing that men are more susceptible of being at risk of exercise addiction, which supports the results obtained by Lichtenstein, Christiansen et al. (2014). Also, as for different participant groups, it was found that athletes are more susceptible to addiction risk compared to students and people who do physical exercise. This result is contrary to what was found by Szabo and Griffths (2007).

It is concluded that EAl is confirmed as an adequate and reliable instrument, with appropriate psychometric properties.

However, this study found several limitations. Firstly, we can mention the lack of scientific studies in our context to identify discriminant validity through use of other scales to identify the concept in the Mexican context. Another study limitation was the wide variety in type of physical exercise performed by study participants. Finally, an important limitation was the scarce scientific evidence of studies in Mexican context that use the EAI scale.
It is suggested that for future research, the following should be taken into account: (1) compare EAl with other instruments that measure exercise addiction and related constructs, (2) perform corresponding analysis to assess the cut-off point to limit and discriminate when people are at risk of suffering from addiction, and when symptoms are present or not, since this study was based on cut-off points established for the British and Spanish context.

\section{References}

American Psychiatric Association. (2013). Diagnostic and statistical manual of mental disorders (DSM-5®). American Psychiatric Pub.

Berczik, K., Szabo, A., Griffiths, M. D., Kurimay, T., Kun, B., Urbán, R., \& Demetrovics, Z. (2012). Exercise addiction: Symptoms, diagnosis, epidemiology, and etiology. Substance Use \& Misuse, 47, 403-417. https://doi.org/10.3109/10826084.2011.639120

Berengüí, R., López-Gullón, J. M., \& Angosto, S. (2021). Physical sports activities and exercise addiction during lockdown in the Spanish population. International Journal of Environmental Research and Public Health, 18, 3119. https://doi.org/10.3390/ ijerph18063119

Berengüí, R., \& Pelegrín, A. (2018). Problemas asociados a la práctica deportiva. In R. Berengüi \& J. M. López-Walle (Eds.), Introducción a la Psicología del Deporte (pp. 451-488). EOS Editorial.

Brown, R. I. F. (1993). Some contributions of the study of gambling to the study of other addictions. In W. R. Eadington \& J. A. Cornelius (Eds.), Gambling behaviour and problem gambling (pp. 241-272). University of Nevada Press.

Bruno, A., Quattrone, D., Scimeca, G., Cicciarelli, C., Romeo, V. M., Pandolfo, G., Zoccali, R. C., \& Muscatello, M. R. (2014). Unravelling exercise addiction: The role of narcissism and self-esteem. Journal of Addiction, 2014(5), 987841. https://doi. org/10.1155/2014/987841

Cheung, G. W., \& Rensvold, R. B. (2002). Evaluating goodnessof-fit indexes for testing measurement invariance. Structural Equation Modelling, 9, 233-255. https://doi.org/10.1207/ S15328007SEM0902_5

Demetrovics, Z., \& Kurimay, T. (2008). Testedzésfüggoség: A sportolás mint addikció. Psychiatria Hungarica: A Magyar Pszichiátriai Társaság tudományos folyóirata, 23, 129-141.

Garman, J. F., Hayduk, D. M., Crider, D. A., \& Hodel, M. M. (2004). Occurrence of exercise dependence in a college-aged population. Journal of American College Health, 52, 221-228.

Griffiths, M. D. (1996). Behavioural addiction: An issue for everybody? Journal of Workplace Learning, 8(3), 19-25.

Griffiths, M. D (1997). Exercise addiction: A case study. Addiction Research and Theory, 5(2), 161-168. https://doi. org/10.3109/16066359709005257

Griffiths, M. D. (2002). Gambling and gaming addictions in adolescence. British Psychological Society/ Blackwells.

Griffiths, M. D., Szabo, A., \& Terry, A. (2005). The exercise addiction inventory: A quick and easy screening tool for health practitioners. British Journal of Sports Medicine, 39, Article e30. https://doi.org/10.1136/bjsm.2004.017020

Griffiths, M. D., Urbán, R., Demetrovics, Z., Lichtenstein, M. B., de la Vega, R., Kun, B., Ruiz-Barquín, R., Youngman, J., \& Szabo, A. (2015). A cross-cultural re-evaluation of the exercise addiction inventory (EAI) in five countries. Sports MedicineOpen, 1, 5-7. https://doi.org/10.1186/s40798-014-0005-5

Goodman, A. (1990). Addiction: Definition and implications. British Journal of Addiction, 85, 1403-1408. https://doi. org/10.1111/j.1360-0443.1990.tb01620.x 
Hausenblas, H. A., \& Symons-Downs, S. (2002). Exercise dependence: A systematic review. Psychology of Sport and Exercise, 3, 89-123. https://doi.org/10.1016/S1469-0292(00)00015-7

Hu, L. T., \& Bentler, P. M. (1999). Cut-off criteria for fit indexes in covariance structure analysis: Conventional criteria versus new alternatives. Structural Equation Modelling: A Multidisciplinary Journal, 6, 1-55. https://doi.org/10.1080/10705519909540118

Jöreskog, K. G., \& Sörbom, D. (2006). LISREL 8.80 for Windows [Computer software]. Scientific Software International.

Kovacsik, R., Griffiths, MD, Pontes, HM, Soós, I., De la Vega, R., Ruíz-Barquín, R. Demetrovics, Z., \& Szabo, A. (2019). The role of passion in exercise addiction, exercise volume, and exercise intensity in long-term exercisers. International Journal of Mental Health and Addiction, 17, 1389-1400. https://doi. org/10.1007/s11469-018-9880-1

Lichtenstein, M. B., Christiansen, E., Bilenberg, N., \& Støving, R. K. (2014). Validation of the exercise addiction inventory in a Danish sport context. Scandinavian Journal of Medicine \& Science in Sports, 24, 447-453. https://doi. org/10.1111/j.1600-0838.2012.01515.x

Lichtenstein, M. B., Griffiths, M.D., Hemmingsen, S. D., \& Stoving, R. K. (2018). Exercise addiction in adolescents and emerging adults - Validation of a youth version of the exercise addiction inventory. Journal of Behavioural Addictions, 7, 117-125. https://doi.org/10.1556/2006.7.2018.01

Lichtenstein, M. B., Larsen, K. S., Christiansen, E., Stoving, R. K., \& Bredahl, T. V. (2014). Exercise addiction in team sport and individual sport: Prevalence and validation of exercise addiction inventory. Addiction Research and Theory, 22, 431-437. https://doi.org/10.3109/16066359.2013.875537

Marques, A., Peralta, M., Sarmento, H., Loureiro, V., Gouveia, E. R., $\&$ de Matos, M. G. (2018). Prevalence of risk for exercise dependence: A systematic review. Sports Medicine, 49, 319333. https://doi.org/10.1007/s40279-018-1011-4

Márquez, S., \& De la Vega, R. (2015). La adicción al ejercicio: un trastorno emergente de la conducta. Nutrición Hospitalaria, 31, 2384-2391. https://doi.org/10.3305/nh.2015.31.6.8934

Mónok, K., Berczik, K., Urbán, R., Szabo, A., Griffiths, M. D., Farkas, J., \& Demetrovics, Z. (2012). Psychometric properties and concurrent validity of two exercise addiction measures: A population wide study. Psychology of Sport and Exercise, 13, 739746. https://doi.org/10.1016/j.psychsport.2012.06.003

Ogden J., Veale, D., \& Summers, Z. (1997). The development and validation of the exercise dependence questionnaire. Addiction Research and Theory 5(4), 343-355. https://doi. org/10.3109/16066359709004348

Pasman, L. N., \& Thompson, J. K. (1988). Body image and eating disturbance in obligatory runners, obligatory weightlifters, and sedentary individuals. International Journal of Eating Disorders, 7(6), 759-769. https://doi.org/10.1002/1098108X(198811)7:6<759::AID-EAT2260070605>3.0.CO;2-G

Sicilia, Á., Alías-García, A., Ferriz, R., \& Moreno-Murcia, J. A. (2013). Spanish adaptation and validation of the exercise addiction inventory (EAl). Psicothema, 25, 377-383. https://doi. org/10.7334/psicothema2013.21

Sicilia, A., Bracht, V., Penha, V., Ribero, U., Ferriz., R., \& Alcaraz-lbañez, M. (2017). Propiedades psicométricas del exercise addiction inventory (EAI) en una muestra de estudiantes brasileños universitarios. Universitas Psychologica, 16(2), 1-10. https://doi.org/10.11144/Javeriana.upsy16-2.ppea
Sicilia, A., \& González-Cutre, D. (2011). Dependencia y ejercicio físico: Validación española de la escala de dependencia del ejercicio - Revisada (EDS-R). Spanish Journal of Psychology, 14(1), 421-431. https://doi.org/10.5209/rev_SJOP.2011.v14.n1.38

Simón-Grima, J., Estrada-Marcén, N., \& Montero-Marín, J. (2019). Exercise addiction measure through the exercise addiction inventory (EAI) and health in habitual exercisers. A systematic review and meta-analysis. Adicciones, 31, 233-249. https://doi. org/10.20882/adicciones.990

Simón-Grima, J., San Martín, A., Estrada-Marcén, M., \& Casterad-Seral, J. (2021). Relación entre la adicción al ejercicio, el uso de dispositivos fitness y la ansiedad rasgo. Retos, 39, 525-531. https://doi.org/10.47197/retos.v0i39.80078

Symons-Downs, D., Hausenblas, H. A., \& Nigg, C. R. (2004). Factorial validity and psychometric examination of the exercise dependence scale - Revised. Measurement in Physical Education and Exercise Science, 8(4), 183-201. https://doi.org/10.1207/ s15327841mpee0804_1

Szabo, A. (1995). The impact of exercise deprivation on well-being of habitual exercisers. Australian Journal of Science and Medicine in Sport, 27, 68-75.

Szabo, A. (1998). Studying the psychological impact of exercise deprivation: Are experimental studies hopeless? Journal of Sport Behaviour, 21, 139-147.

Szabo, A. (2000). Physical activity and psychological dysfunction. In S. Biddle, K. Fox, \& S. Boutcher (Eds.), Physical activity and psychological well-being (pp. 130-153). Routledge.

Szabo, A., de la Vega, R., Ruiz-Barquín, R., \& Rivera, O. (2013). Exercise addiction in Spanish athletes: Investigation of the roles of gender, social context and level of involvement. Journal of Behavioural Addictions, 2, 249-252. https://doi.org/10.1556/ JBA.2.2013.4.9

Szabo, A., \& Griffths, M. (2007). Exercise addiction in British sport science students. International Journal of Mental Health and Addiction, 5, 25-28. https://doi.org/10.1007/s11469-006-9050-8

Terry, A., Szabo, A., \& Griffiths, M. D. (2004). The exercise addiction inventory: A new brief screening tool. Addiction Research and Theory, 12, 489-499. https://doi.org/10.1080/1606635031 0001637363

U.S. Department of Health and Human Services (2008). Physical activity guidelines for Americans: Be active, healthy and happy! https://health.gov/paguidelines/pdf/paguide.pdf

Villella, C., Martinotti, G., Di Nicola, M., Cassano, M., La Torre, G., Gliubizzi, M. D., \& Conte, G. (2011). Behavioural addictions in adolescents and young adults: Results from a prevalence study. Journal of Gambling Studies, 27(2), 203-214. https://doi. org/10.1007/s10899-010-9206-0

Wheaton, B., Muthen, B., Alwin, D. F., \& Summers, G. (1977). Assessing reliability and stability in panel models. Sociological Methodology, 8, 84-136. https://doi.org/10.2307/270754

Youngman, J., \& Simpson, D. (2014). Risk for exercise addiction: A comparison of triathletes training for sprint-, olympic-half-ironman-, and ironman-distance triathlons. Journal of Clinical Sport Psychology, 8(1), 19-37. https://doi.org/10.1123/ jcsp.2014-0010 